\title{
Influence of cultural practices on food waste in South Africa-a review
}

\author{
Lethabo Phasha* (D, Gomotsegang F. Molelekwa, Matlou I. Mokgobu, Thabiso J. Morodi, Michael M. Mokoena and \\ Lutendo S. Mudau
}

\begin{abstract}
Background, aim, and objectives: The purpose of the review is to assess the cultural practices and its influence on food waste in South Africa. Furthermore, it explores the reasons for food waste by looking at different cultural practice of various ethnic groups in South Africa. The growing concern of the challenges of waste on human health and the environment has pressured the world to come up with drastic measures on how to manage waste to reduce both environmental and public health impacts. One of the concerns is that food waste has become one of the main contributors to increased greenhouse gas emissions. However, South Africa does not have stringent measures to control or reduce food waste in its communities.

Methods: An extensive online search was conducted to assess the influence of culture on food waste in South Africa and explore how other countries' cultural practices contribute to food waste. Information was retrieved from online reports, journals, and books.

Results and conclusions: The studies showed a diversity of cultures and practices in South Africa compared to other countries. For example, in affluent countries where food is available in large quantities, cultural practices have a major influence on food waste. Moreover, some studies highlighted the fact that even though most developing countries are overwhelmed by poor people, many of whom live below the poverty line, food waste is also a challenge. In South Africa, food waste generated during social activities that are related to cultural practices remains a serious challenge. This is because during the cultural and social events, food is prepared in large quantities, which ends up not being wholly consumed and resulting in an increase in food waste that gets disposed of at the landfill sites. The government of South Africa must institute awareness raising measures to inform communities to avoid or reduce the generation of food waste. This would reduce the emission of greenhouse gases and environmental impact, and to protect human health.
\end{abstract}

Keywords: Food waste, Cultural practices, South African cultures, Western culture, Poverty culture, Wealthy culture

\section{Introduction}

Cultural practices influence our daily livelihoods including the perception of food waste. Food loss or food waste has become a very important topic around the globe due to its impact on the environment, health, and economy. Food waste impacts the environment negatively and the management of wasted food entails costs within energy and water sectors [1]. Consequently, when

* Correspondence: PhashaL@tut.ac.za; phashalethabo@gmail.com Department of Environmental Health, Tshwane University of Technology, P/ Bag X680, Pretoria 0001, Republic of South Africa food is wasted, methane and carbon dioxide are released into the atmosphere which increases global warming [2]. Food waste differs from one culture to another irrespective of the country's development.

Cultural differences bring about variation in reasons. These reasons have been advanced in both developed and developing nations in respect of why people waste food. There is a great spectrum of reasons that may lead to food waste but at this point, it is greatly evident that developed countries such as the UK and the USA substantially increase food waste in the fields because of

(c) The Author(s). 2020 Open Access This article is licensed under a Creative Commons Attribution 4.0 International License, which permits use, sharing, adaptation, distribution and reproduction in any medium or format, as long as you give appropriate credit to the original author(s) and the source, provide a link to the Creative Commons licence, and indicate if changes were made. The images or other third party material in this article are included in the article's Creative Commons licence, unless indicated otherwise in a credit line to the material. If material is not included in the article's Creative Commons licence and your intended use is not permitted by statutory regulation or exceeds the permitted use, you will need to obtain permission directly from the copyright holder. To view a copy of this licence, visit http://creativecommons.org/licenses/by/4.0/. 
their policies for fresh produce [3]. In these affluent countries, food is in abundance and at affordable prices, which then influences a certain culture on how food is valued and the amount of food that is wasted by the residents [4]. Again, the intentional destruction of food is becoming popular in affluent countries and the world needs to be concerned. Factors such as age, awareness, and attitude play a significant role when it comes to valuing food. In Spain, for example, there is an annual cultural festival called the "La Tomatina" were 110-155 tons of tomatoes are destroyed during what is considered the world's largest food fight [5]. This has inspired a similar cultural practice in other countries such as Columbia, Costa Rica, China, and Nevada [5] which clearly has a major impact on the environment.

Again in 2009, anger became the ultimate treason to food conservation during a continental strike in Europe, whereby more than 80,000 farmers spilled millions of liters of milk on the ground. The intent was to force the European Union to combat plunging milk prices that were financially ruining them [6]. Unfortunately, this contributed to food waste and added to the plight the world is fighting for; reducing the impact of climate change and environmental sustainability.

Concurrently, the developing countries also contribute to food waste. It has been highlighted that Sub-Saharan African and South East Asia have high wastage of food, which is predominantly and primarily occurring at the farmer-producer stage of the supply chain [3]. As such it is a worrying fact that as a consequence, 4 billion tonnes of food produced in the world annually for human consumption ends up being wasted [7]. Accordingly, Tiwari pointed out that [8] this amount of food may be sufficient to feed over 12 billion people even though the world's population is estimated at 7.6 billion [9] and a third of the food produced goes to waste [10]. It is therefore unfortunate that in developing countries, including African countries, food waste is not given the serious attention it deserves, which is shown by the limited interventions measures implemented so far to address this challenge. It is also a shame that such amount of food is wasted when the magnitude of malnourishment in Africa has reached unprecedented crisis levels and whereby the majority of the world poor nations are bearing the brunt of these unfortunate episodes with resultant unnecessary deaths from hunger [11]

As the number of the affluent nation's increases, so does the culture of wastefulness that is gaining momentum while poor people are left with less food. With less food available for the poor, a new way of survival becomes all about saving and using the absolute minimal. This has become a way of doing things for the poor and led to a culture of poverty. Lewis [12] describes the "culture of poverty" as lacking the knowledge to alleviate yourself from poverty conditions, and added that it becomes autonomous, as behaviors and attitudes developed within this culture get passed down to subsequent generations through socialization processes.

South Africa, like Brazil and Malawi, is a developing country with a lot of challenges [11] such as food insecurity. It is estimated that about 10 million tonnes of food is wasted every year in South Africa whereas millions of its populace go to bed hungry each night [13]. One of the discerning challenges that are pertinent includes food wastage. Fox [3] argues that as countries develop economically, their wastage of food has the propensity of moving higher up the food chain, which in turn makes food wastage a dominating problem in the middle- and high-income countries [14]. Ex post facto, consumers tend to believe that food waste is inevitable and it is rather a fact of life. In a report compiled by the world wildlife fund [13]; it is stated that South Africa has committed itself to reducing food waste by $50 \%$ by the year 2030 following the United Nations Sustainable Development Goals (SDG) summit meeting, which was held on the 25-27 September 2015 at the United Nations Headquarters in New York. It also stated that most of the food is wasted at post-harvest activities; hence, little is known on how much food gets wasted in households and the retrospective influence brought by the variety of cultures in the country. Thus, if total food waste is known and prevented, the available food could feed millions of people going hungry every day.

South Africa is known to be the "Rainbow Nation" which is defined as "A multi-racial or multi-cultural country [15]. This means that there is a great variation in terms of ethnicity, language, race, physical appearances, values, behaviors, etc., which display different cultural practices. Culture in the lives of South Africans is deeply embedded, and so most lifestyles are reliant on it to the extent that it may influence habits that could be deleterious to both the environment and health. Ipso facto, the understanding of cultural practices on the impact of food waste cannot be ignored. For instance, there is a phenomenon known as Izikhotane, which is a group of youngsters who show off their wealth by destroying expensive clothes and food [16]. This is a cultural practice that is being influenced by a person's "socio-economic level" and is commonly referred to as "culture of the rich" or the poor [17]. This practice indicates a gap that still is to be addressed in South Africa concerning the prevention and control of food waste.

Culture is described from the 19th century as the customary beliefs, social forms, and material traits of a racial, religious [18], or social group; the characteristic features of everyday existence shared by people in place or time [19]. Ethnic foods evolved from human culture and the phenomena of human biology have significant 
socio-cultural values. In respect of culture, South Africa is denoted by the languages spoken such as Sesotho, Setswana, and Sepedi (Basotho clan); IsiZulu, siSwati, IsiNdebele, and IsiXhosa (Nguni group) and also Xitsonga, Tshivenda, English, Afrikaans, etc., which have different teachings and values that greatly impact the way people perceive and value things [20]. The review, therefore, focused on how different cultures particularly African culture in general and other western cultures would influence food waste with respect to South African culture.

Extensive research has been done worldwide that attempted to identify the most specific and related reasons why there is so much food wasted. However, most of the researchers looked at the consumer-related influence and the Food Supply Chain [21]. There is very limited research done that focuses on personal attributes such as a culture that may influence or cause food to be wasted. This article intends to outline how different cultures contribute to food waste. It particularly focused on socio-cultural activities such as weddings, funerals, parties, and other celebrations that contribute to food waste. The article further sought to determine the increase or decrease of food waste by identifying the common trends, norms, practices, and behaviors that contribute to food waste.

\section{Methodology}

An extensive online desktop study was used following a narrative approach and analysis of various reports, peerreviewed articles, and books. Due to the limited information available, different kinds of searches were employed making the study to take a narrative orientation; the main idea is to explore how culture influences food waste and to determine its impact on the waste stream and the environment. The authors searched for information by using keywords that included food waste, cultural practices, South Africa, Western culture, poverty, eating disorder. The engine search methods used were Google search, Google Scholar, and PubMed. In Google search, a large number of reports and articles relevant to the topic were found. In Google scholar, 124 articles were found but only 7 were online with the food waste and culture. In PubMed, the search was done using the words "food waste and culture" and 924 articles were found but because the number was too large the search was redefined to "food waste by cultural factors," and 129 articles appeared, and 5 five were relevant to this article. Information retrieved was analyzed in terms of cultural practices and food waste for Western and African cultures with more focus on South African culture. However, despite cultural food waste search; other vital information outlining what is happening worldwide in terms of food waste was also considered.

\section{General overview of food waste}

Food consumption in developing countries is relatively lower than that of industrialized countries [22]. In developing countries, the average amount of food waste equals $30 \%$ of the total food produced, and it is happening in regions where $13 \%$ of children under 5 years of age are undernourished and undersized due to nutrient deprivation [23]. Food waste is usually not equated to an economic value which then under signifies the total cost of waste (Fig. 1).

An average South African wastes $12 \mathrm{~kg}$ of food per annum as individual in other Sub-Saharan African Countries as shown in Table 1 below. According to McCracken [30] in 2017 an American individual wasted an average of $287 \mathrm{~kg}(632 \mathrm{lb})$ of food per annum. Given the evidence that the total amount of food produced directly influences the amount of food wasted in regions producing a higher amount of food, Table 1 shows an increased amount of food wasted per individual in developed countries, South Africa, and other countries in Sub-Saharan Africa.

The relationship between population and food waste is shown in Fig. 2. This figure shows that an increase in the population led to an alleviated chance of increased food waste. Ross [31] posited that the USA is part of the top four countries that produce the highest amount of food in the world. Pursuant to that, World Economic Forum [26], reported that the top seven countries that show the greatest food waste contribution includes both the USA and Europe. In that respect, it is clear that most industrialized western countries tend to produce more waste in excess of $40 \%$ of their total production.

\section{Western cultures}

According to Dawson [32], "Western culture is equated to Europeans civilization because their heritage of social norms, ethical values, traditional customs, belief, and political systems and technologies are associated with Europe." People's culture is what makes them distinctive from the rest of society [33]. The social norms of the western culture are centered on individualism and their inherent uniqueness [34]. Specific traditional or cultural practices can either be beneficial or harmful to the environment [35]. Markwell [36] states that it is a norm in the Western culture to "bin food," as the supermarkets make it easy for westerners to throw away food with their food sale promotions.

However, there is a claim that Westerners are more analytic than the rest of the world, and in terms of food preparation for events, Baer [17] says that Westerners carefully analyze all costs they may incur, which suggests that they waste less food as they prefer small events. Furthermore, they believe that preparing food at a funeral is to help the mourners cope with the death of their loved one, and if you do not share a meal after the funeral you are considered to be rude [37]. However, 


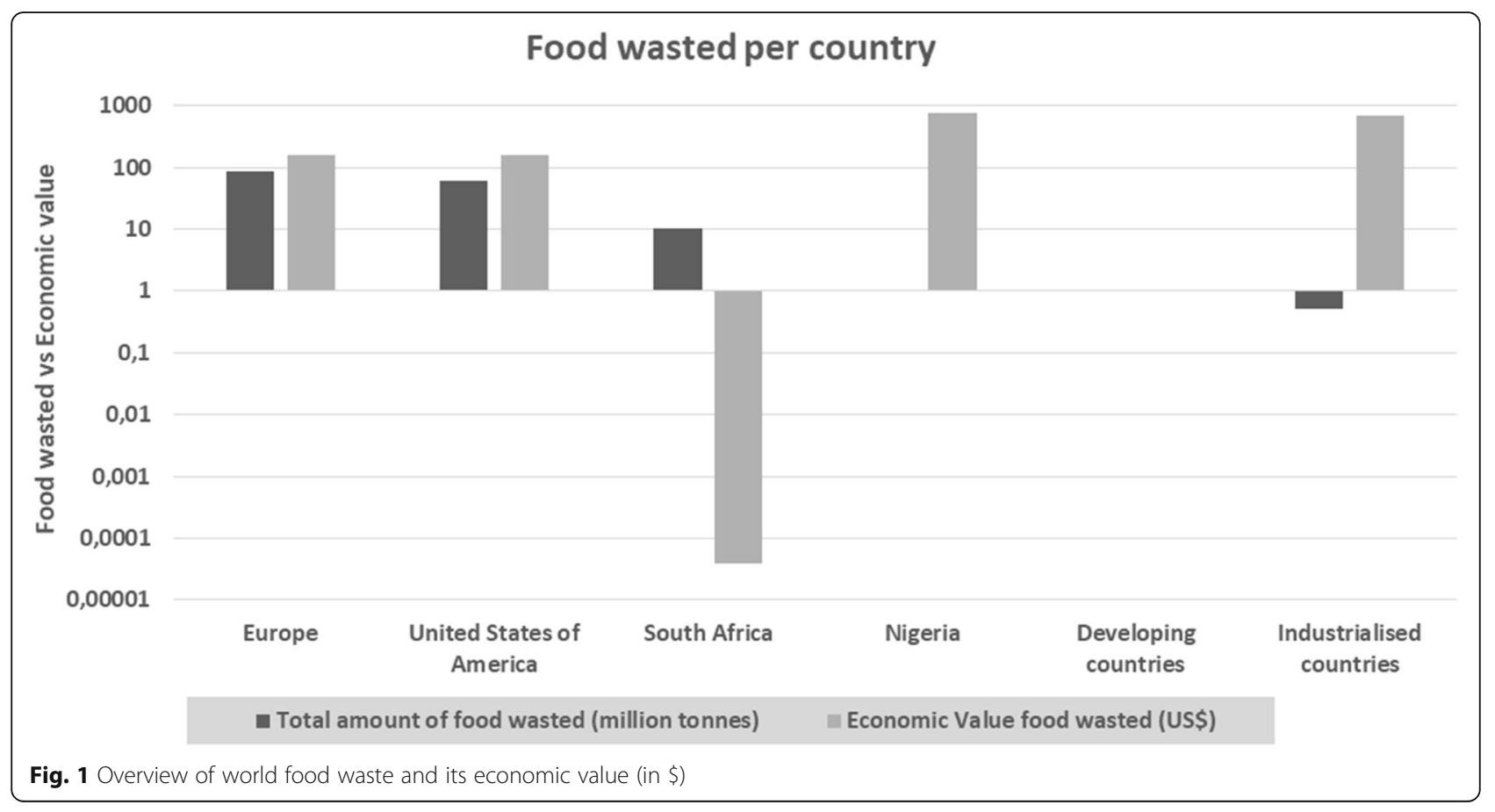

most Americans are comfortable to share a meal. Their practice of sharing a meal would help avoid food waste. In that view, funerals are mostly celebrated with tea and sandwiches [38] and thus less food is prepared and less food is likely to be wasted.

When it comes to weddings and parties, catering and admission into the venue is done specifically for the number of people that have RSVP'd to the invitation. This is commonly referred to as "wedding etiquette" [39]. This strict rule greatly minimizes food waste as only those people who have been invited and confirmed that they would attend the event are being catered for, and also the issues of dietary requirements such as vegetarian, halaal etc., like African cultures whose food practices are diverse are being catered for.

\section{African cultures}

Whereas the African culture is enigmatic, its tradition is however inaccessible since it is oral and not written, lived, and not formally communicated in books or journals [40]. The African culture is diverse, and it is not only about extravagance but also caring for the next person in the spirit of "Ubuntu." "Ubuntu is a social philosophy, a way of being, a code of ethics and behavior deeply embedded in African culture" [40]. It includes the sharing of wealth, housing, and food. Food, therefore, is used to show love and acceptance and is associated with happiness, [16].

This African culture is composed of various nationalities, different languages are spoken, and they eat different food, and even have different greeting habits.

Table 1 Amount of food wasted by individuals in developed and developing countries

\begin{tabular}{llll}
\hline Demographic location & $\begin{array}{l}\text { Amount of food } \\
\text { produced }\end{array}$ & $\begin{array}{l}\text { Amount of food wasted per } \\
\text { individual }\end{array}$ & References \\
\hline Europe & ND & $173 \mathrm{~kg} /$ person/annum & Stenmarck, 2016 [24], (European Parliament)) \\
USA & $>120$ million tonnes & $287 \mathrm{~kg} /$ person/annum & USDA, 2018 [25] World Economic Forum 2015 [26] \\
$\begin{array}{l}\text { Sub-Saharan Africa (Excluding } \\
\text { SA) }\end{array}$ & 230 million tonnes & $6-11 \mathrm{~kg} /$ person/annum & UNEP and FAO, 2013 [10], Nahman 2012 [27] \\
South Africa & 31 million tonnes & $8-12 \mathrm{~kg} /$ person/annum & Oelofse, 2013 [28], Molelekwa, 2018 [29], WWF, 2017 \\
Nigeria & ND & ND & [13] \\
Developing countries & 630 million tonnes & ND & Onwumere, 2018 [23] \\
Industrialized countries & 670 million tonnes & ND & UNEP and FAO, 2013 [10] \\
\hline
\end{tabular}

*ND not detected 


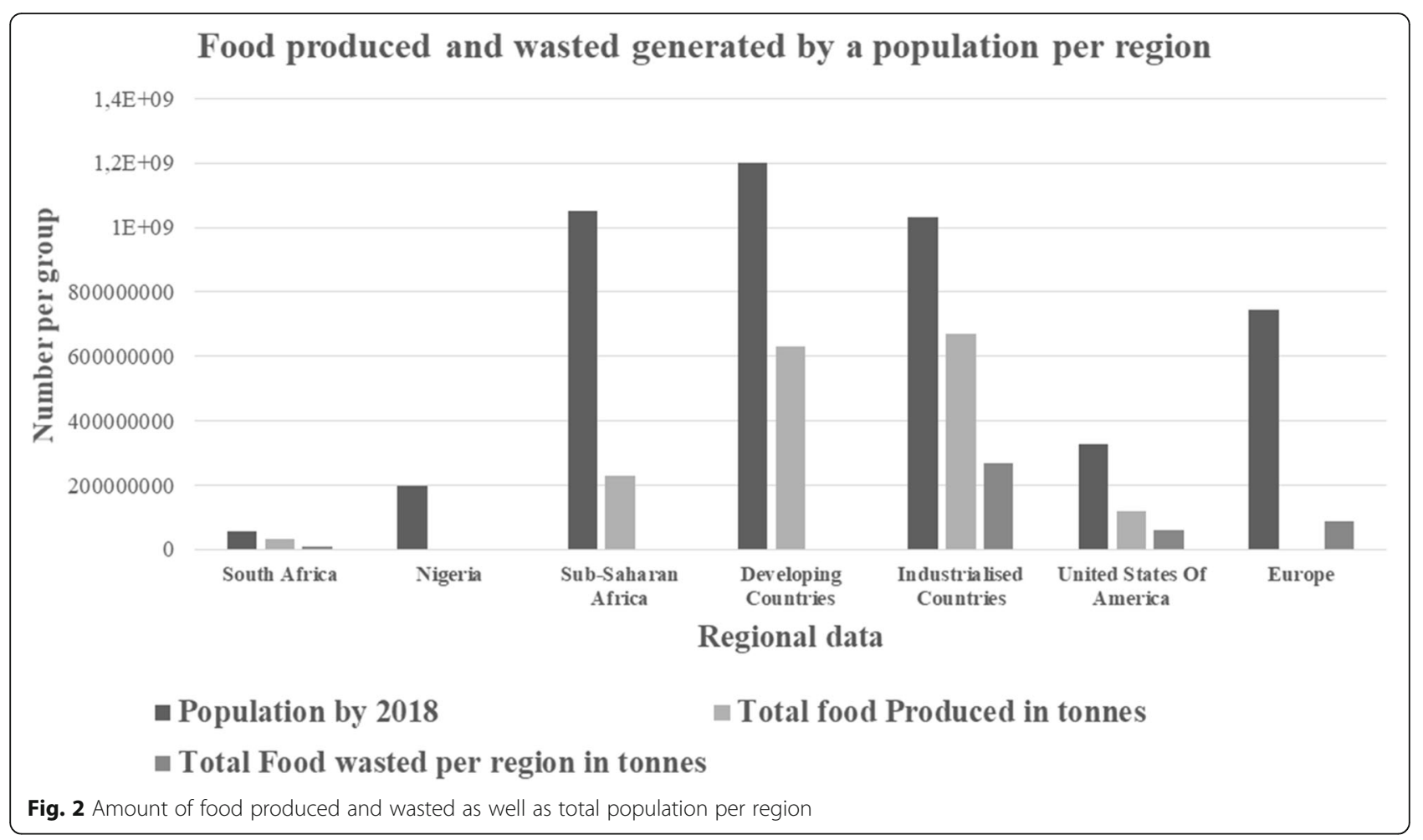

Despite these differences in cultures, they still share common values that set them apart from the rest of the world [33]. In an African society, social values are not separated from religious, political, and moral values [33] as they form the undertone that influences the life choices of the African people. The most important thing at any ceremony is the amount of food you prepare, one ought not to disappoint their guests or starve them. This practice alone creates pressure and the potential for food waste per social event. Almost all of the ceremonial occasions in Sierra Leone demand the preparation of large platters of rice that get distributed to the guests until they are full [41]. This means that large amounts of food must be prepared to allow for the continuous feeding of the guests, which has a potential of increasing the chances of food waste. Another example is the annual "New Yam Festival"; an indigenous traditional celebration of certain Nigerian people, where yam is celebrated after a year of successful cultivation [42]. During the evening preceding the festival all the yam from the previous cultivation year is either eaten or discarded [42]. This is done because it is believed that the New Year should start with fresh new yams. Discarding of yam that is still edible constitutes to food waste, they should rather donate it to other regions of Nigeria that do not share the same belief.

In East Africa (Somalia to Northern Mozambique), a Swahili wedding is never complete without the biriyani for lunch because it is their favorite [43]. Biriyani is a special type of food that is prepared from recipes that have not changed over the years for the Swahili culture [43]. This implies that the food prepared is most likely to be enjoyed and finished resulting in minimal food waste.

There are still much more wasteful practices in African culture. Africans have adopted a new social aspect, wherein funerals are treated as big social events, and the catering has to be even bigger [44]. The eruption of this culture concludes that the "success" of a funeral is determined by the casket and the food provided [44], and so to keep up with this, large amounts of food are prepared. For instance, in Nigeria, funerals have become an extended weekend-long party wherein all and sundry participate as a way of celebrating the life of the deceased [45]. During such time, food is prepared at least three times a day irrespective of whether the mourners have had enough or not. The norm is that if food is offered to you in African culture, you may not refuse the food served as this will be seen as disrespecting the deceased family, mourners, and the departed soul. Hence, more and more meals are prepared without the consultation of people that are meant to eat it, which results in food being wasted, and this is also happening at wedding ceremonies.

To take the above argument further, Zama Kodwa [46] posits that in the African culture, there is no such thing as a guest list or invitations for a traditional wedding since the assumption is that "everyone is invited." This, therefore, means that the whole community will be attending, whether or not they know the individual or the family. Preparation of the food is done in the morning 
and in large fire pots before the guests arrive. As such, it is not possible to accurately estimate the number of guests that will be attending the ceremony, and as a result, it is not possible to avoid unnecessary food waste.

Given that, it is clear that African cultures are variant since invitations and specific catering protocol does not exist. These practices inadvertently place the bereaved family in an untenable and precarious situation of having to deal with large quantities of waste from either leftovers or large amounts of waste. On the other hand, other African practices avoid food waste by allowing the men to eat first and the women eating what is left over. All these issues highlighted present us with a huge headache in that they demonstrate how cultural practices may unwittingly impact on the waste generation dilemma. Pursuant to that, the issues of culture and food waste are connected and related in a broad sense since the said cultural practices, though short term, have the propensity of impacting on poverty alleviation strategy. Including but not limited to the environmental impact that may ensue from the cultural practices.

\section{South African cultures}

South Africa's population is complex hence it is given the term "rainbow nation"; the composition of its diverse population (51.7 million) is as follows: over 41 million are black, 4.5 million are white, 4.6 million are colored, and about 1.3 million are Indian or Asian [47]. The diversity of South African cultures makes it peculiar. Above all, the cultures are differentiated by the eleven official languages [48]), namely, English, Afrikaans, their race is white and isiZulu, isiXhosa, isiNdebele, siSwati, Sesotho, Sepedi,
Setswana, Tshivenda, and Xitsonga (Fig. 3), whose race is black; this also influences how they behave, interact, and value things. Afrikaans is the most spoken official language, and Ndebele is the least; however, Zulu is the most popular language among the black South Africans, as shown in Fig. 3 below.

Food is important for South Africans not only for nutrition but it is also an integral part of the cultural heritage, national identity, and has a symbolic meaning that is more than what one could see on the plates since it also serves as a connection between friends and families [50]. Homogeneity in South African cultures does not exist; however, different cultures are predominant in different regions of the country as shown in the geographical map in Fig. 4 below, which was also influenced by previous injustices against the black racial group.

In South Africa, it is important to follow all the cultural rules, they are inherently oral in that what people were taught at a young age ought to be and carried over to subsequent generations. Women are for instance taught that "a way to a man's heart is through the stomach," and this teaching right or wrong including other rules such as "a man must eat in his home, or else it means he is an adulterer" has the possibilities of contributing to food waste. For example, wives from the northern part of South Africa (Limpopo) are taught to never serve their husbands a cold meal or leftovers, and this added burden contributes to the volume of waste generated as such food gets discarded even though it is still edible.

According to Ndinisa [45], during ceremonies in South African cultures, the host needs to serve to impress. This is perceived more as a lifestyle and status particularly in

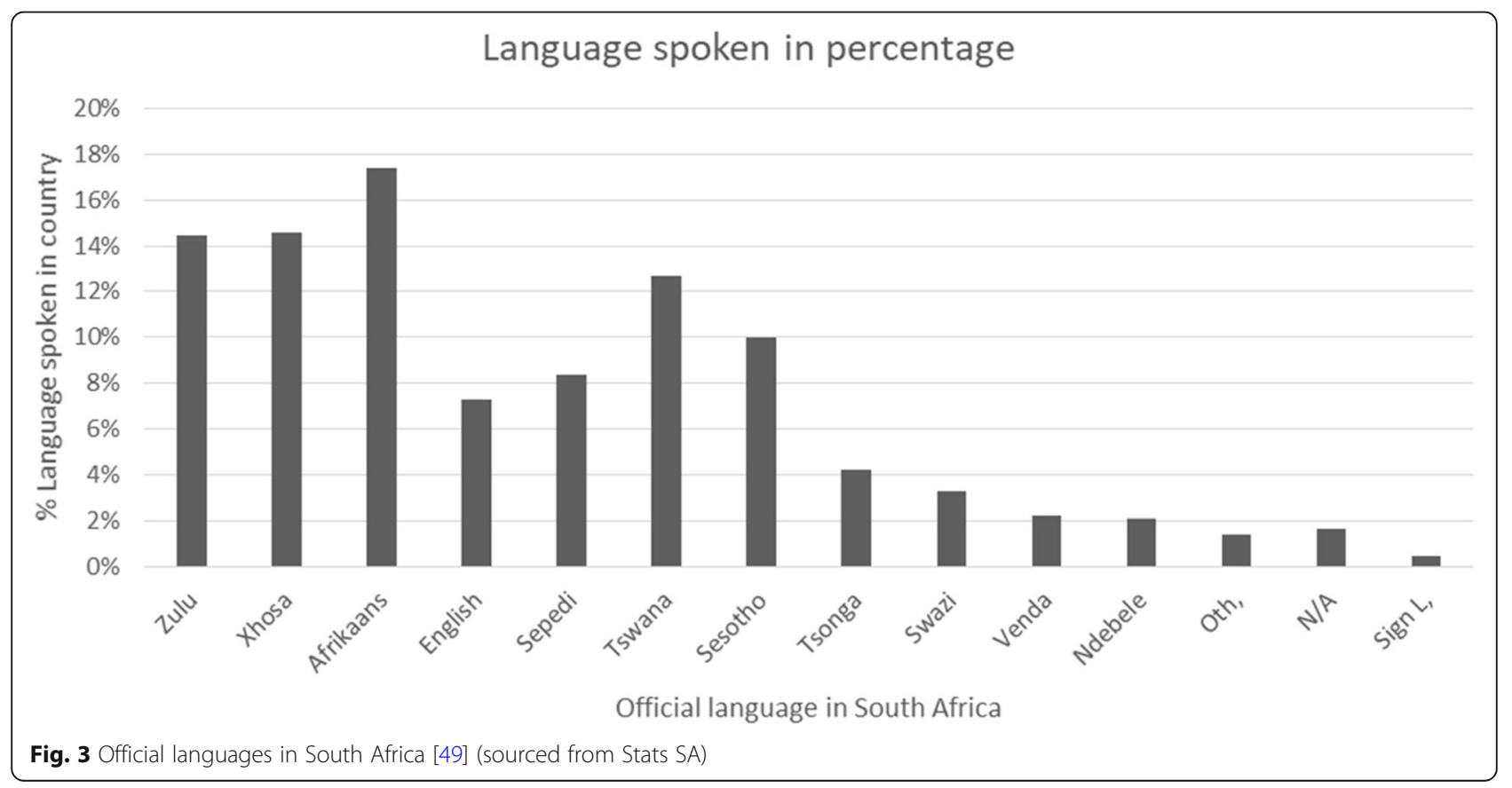




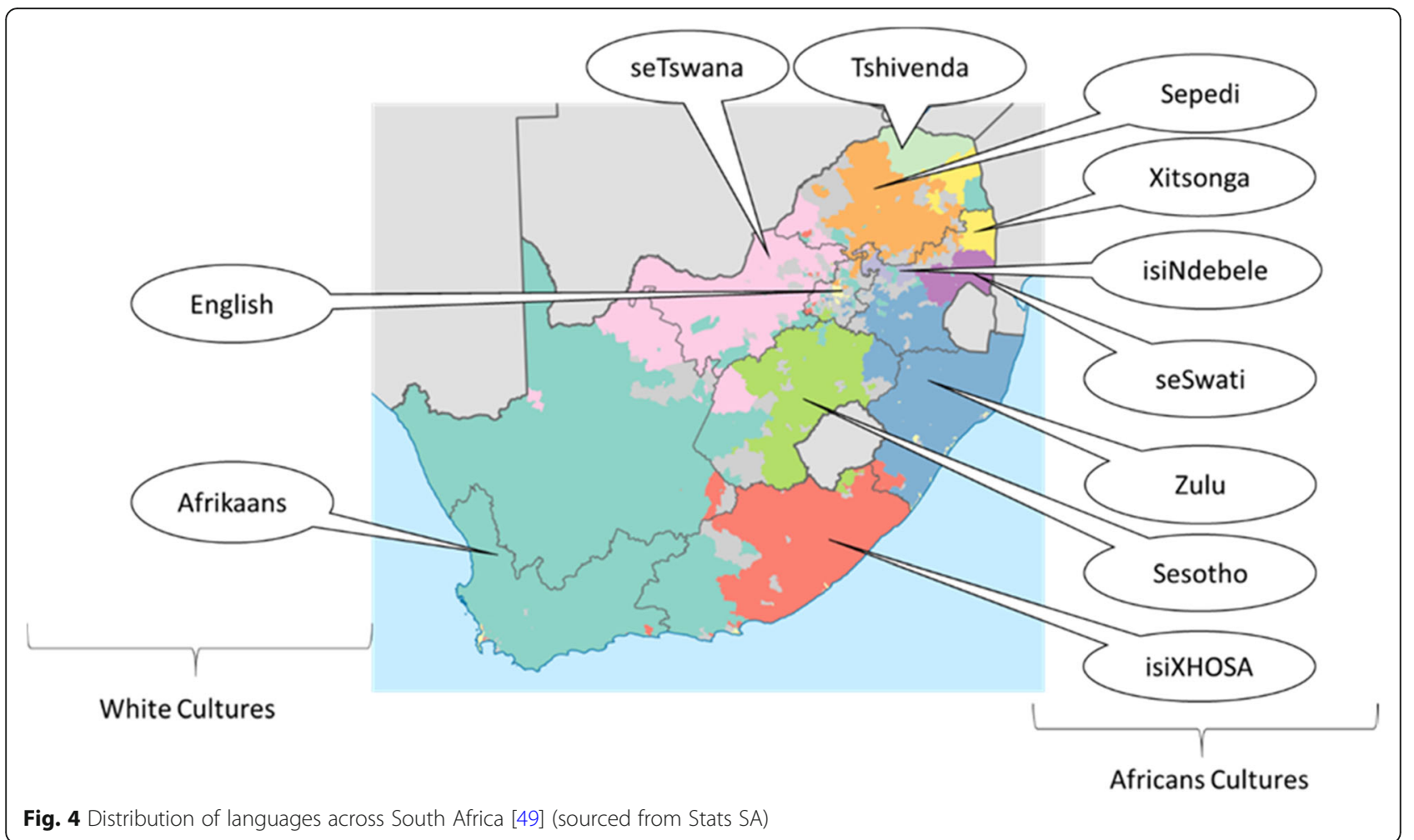

certain clans, and these are reputational in that they will place you at a certain level of respect depending on how you went out impressing those who will be attending the "function." Unfortunately, these practices will unwittingly create a secondary problem of waste generation and the correspondence environmental challenge they may pose.

\section{South African cultural practices in relation to weddings and funerals}

A wedding resembles a time for festivities in South Africa. In most cultures the host is normally unaware of the turnout because invitations are not used. For the host to not disappoint people, large amounts of food are prepared for the guests and gate crashers [45]. "Too much food is cooked, prepared, and served, resulting in leftovers" which may include burnt food [51]. If the turn-out is far less than the amount of food prepared, it gets discarded as most people do not want to be seen taking home food from a wedding or funeral. The tendency to "piggy bag" is deplorable and heavily criticized as it is seen as being uncultured or even make people to be perceived as being paupers.

The slaughtering of the cow is a great part of most South African funerals and weddings, and it occurs a day before the funeral or the wedding or on the day of the wedding as a sacrificial offering for the ancestors [46]. In the case of a wedding, the distribution of specific organs of cow's meat to specific members of the family varies per culture. In the Sepedi culture, the person who is responsible for slaughtering the cow gets to eat the liver immediately after slaughtering. The heart is given to the most senior male of the house and the senior female gets the tripe and shares it with other members of the family whereas the rest of the meat is for the public [52]. The greatest challenge however eventuates in instances where communities do not attend the wedding or funerals in large numbers; more food tends to be wasted. Table 2 below shows different cultural food preparation practices during funerals and weddings.

Table 2 shows how South African cultures differ in terms of staple food and some similarities that are in the preparation and celebrations of events that include weddings and funerals in particular. Food preparations in both funerals and weddings depend on their preferences and influence their staple food and mixed cultural practices. Most generations are becoming more westernized and deviate from traditional dishes due to mixed cultures and urbanization. Hence, westernized culture is becoming more dominant in the cities and are no longer isolated like previously in apartheid years. Thus, adopting a new culture is evident looking at the type of food prepared at weddings and funerals. One other factor is that some people are now wary of their diet and consumption of food becomes minimal. There are a lot of myths in the Xhosa culture around the consumption of food i.e. women at childbearing age/pregnant women are forbidden from eating foods like red meat, chicken, 
Table 2 Various South African cultures and food prepared during weddings and funerals

\begin{tabular}{|c|c|c|c|c|c|c|c|c|}
\hline \multirow[t]{2}{*}{ Culture } & \multirow[t]{2}{*}{ Staple food } & \multicolumn{3}{|c|}{$\begin{array}{l}\text { Food prepared at weddings/ } \\
\text { funerals }\end{array}$} & \multirow[b]{2}{*}{$\begin{array}{l}\text { Sandwich/ } \\
\text { scones }\end{array}$} & \multirow[b]{2}{*}{$\begin{array}{l}\text { Who prepares } \\
\text { the food }\end{array}$} & \multirow[b]{2}{*}{ Invitations } & \multirow[t]{2}{*}{ Consequences } \\
\hline & & Starch & Meat & Salad & & & & \\
\hline & Africans & & & & & & & \\
\hline Zulu & $\begin{array}{l}\text { Meat, phutu (crumbly maize } \\
\text { porridge) sweet pumpkin and } \\
\text { boiled amadumbe, a type of } \\
\text { tuber or yam) }\end{array}$ & $\begin{array}{l}\text { Steamed } \\
\text { bread/ } \\
\text { Phuthu }\end{array}$ & $\begin{array}{l}\text { Chicken/ } \\
\text { beef }\end{array}$ & $x$ & & $\begin{array}{l}\text { Close relatives } \\
\text { and neighbours }\end{array}$ & No & $\begin{array}{l}\text { Lots of food is prepared in the } \\
\text { anticipation that there will be a huge } \\
\text { turn-up, but if many people do not pitch } \\
\text { up, a lot of food may be wasted. }\end{array}$ \\
\hline Xhosa & $\begin{array}{l}\text { Umphokoqo, a crumbly maize } \\
\text { meal with sour milk or } \\
\text { buttermilk } \\
\text { Umxhaxha is a combination of } \\
\text { pumpkin and corn }\end{array}$ & $\begin{array}{l}\text { Samp/ } \\
\text { pap }\end{array}$ & $\begin{array}{l}\text { Mostly } \\
\text { beef and } \\
\text { chicken }\end{array}$ & $x$ & & $\begin{array}{l}\text { Close relatives } \\
\text { and neighbors }\end{array}$ & No & $\begin{array}{l}\text { Cow to be slaughtered the morning of } \\
\text { the ritual, and if the cow bellows, it is } \\
\text { believed that the ancestors have } \\
\text { accepted it if not the sacrifice will not } \\
\text { continue. }\end{array}$ \\
\hline Sepedi & $\begin{array}{l}\text { Thophi (made from maize } \\
\text { meal and a melon), mashotja } \\
\text { (Mopani worms), morogo }\end{array}$ & Pap & $\begin{array}{l}\text { Chicken/ } \\
\text { beef }\end{array}$ & $x$ & Scones & $\begin{array}{l}\text { Men and } \\
\text { Women in the } \\
\text { family. }\end{array}$ & No & $\begin{array}{l}\text { Younger men prefer food prepared by } \\
\text { the women; this will mean more food } \\
\text { will be wasted from "Banna ba kgoro". }\end{array}$ \\
\hline Sesotho & $\begin{array}{l}\text { Ting (grinded sorghum, millet, } \\
\text { and maize) with } \\
\text { Mangangajane are sundried } \\
\text { vegetables. Leqebekoane and } \\
\text { oxtail }\end{array}$ & Pap & $\begin{array}{l}\text { Chicken } \\
\text { and beef }\end{array}$ & $x$ & Scones & $\begin{array}{l}\text { Relatives and } \\
\text { neighbours }\end{array}$ & No & $\begin{array}{l}\text { Overestimation of attendance leads to } \\
\text { overcooking. }\end{array}$ \\
\hline Tsonga & $\begin{array}{l}\text { Xigugu, Tihove (kind of samp), } \\
\text { Tshopi, mealie meal, Xigwimbi, } \\
\text { Vukanyi and matomani } \\
\text { (Mopani worms) }\end{array}$ & $\begin{array}{l}\text { Samp/ } \\
\text { pap }\end{array}$ & $\begin{array}{l}\text { Chicken } \\
\text { and beef }\end{array}$ & $x$ & & $\begin{array}{l}\text { Relatives, } \\
\text { friends, and } \\
\text { neighbors }\end{array}$ & No & $\begin{array}{l}\text { Overestimation of attendance leads to } \\
\text { overcooking. }\end{array}$ \\
\hline Swati & $\begin{array}{l}\text { Sorghum and maize with goat } \\
\text { meat }\end{array}$ & Pap & $\begin{array}{l}\text { Beef/goat/ } \\
\text { chicken }\end{array}$ & $x$ & & $\begin{array}{l}\text { Relatives, } \\
\text { friends, and } \\
\text { neighbors }\end{array}$ & No & $\begin{array}{l}\text { Overestimation of attendance leads to } \\
\text { overcooking }{ }^{c} \text {. }\end{array}$ \\
\hline Ndebele & $\begin{array}{l}\text { Maize cereal (isitshwala), corn } \\
\text { and sorghum milk }\end{array}$ & $\begin{array}{l}\text { Mielie } \\
\text { pap }\end{array}$ & $\begin{array}{l}\text { Beef/ } \\
\text { chicken }\end{array}$ & $x$ & & $\begin{array}{l}\text { Relatives, } \\
\text { friends, and } \\
\text { neighbors }\end{array}$ & No & $\begin{array}{l}\text { Overestimation of attendance leads to } \\
\text { overcooking. }\end{array}$ \\
\hline Setswana & $\begin{array}{l}\text { Bogobe (porridge made from } \\
\text { sorghum (ting) served with } \\
\text { madila (sour goat/cow milk) }\end{array}$ & Pap & $\begin{array}{l}\text { Shredded } \\
\text { meat } \\
\text { (Setswana) }\end{array}$ & & & Family & & $\begin{array}{l}\text { Overestimation of attendance leads to } \\
\text { overcooking }\end{array}$ \\
\hline \multirow[t]{2}{*}{ Venda } & $\begin{array}{l}\text { Tshidzimba, which is a mixture } \\
\text { of beans, groundnuts, and } \\
\text { maize. Mopani worms }\end{array}$ & Pap/rice & & $x$ & & $\begin{array}{l}\text { Close relatives, } \\
\text { friends, and } \\
\text { neighbors }\end{array}$ & No & $\begin{array}{l}\text { Overestimation of attendance and } \\
\text { cooking more than required. }\end{array}$ \\
\hline & White & & & & & & & \\
\hline English & $\begin{array}{l}\text { Sunday roasts, fish and chips, } \\
\text { full English breakfasts, and } \\
\text { Shepherd's Pie. }\end{array}$ & Rice & $\begin{array}{l}\text { Chicken/ } \\
\text { fish }\end{array}$ & $x$ & $x$ & Usually catering & Yes & $\begin{array}{l}\text { During events little food is wasted as } \\
\text { catering is done as per RSVP. }\end{array}$ \\
\hline Afrikaans & $\begin{array}{l}\text { Sosaties(kebab) chicken } \\
\text { sausage, and steak served with } \\
\text { Stywepap }\end{array}$ & Stiff pap & $\begin{array}{l}\text { Chicken/ } \\
\text { beef }\end{array}$ & $x$ & Koeksister & $\begin{array}{l}\text { Men braai the } \\
\text { meat and } \\
\text { women } \\
\text { prepare pap } \\
\text { and salads. }\end{array}$ & Yes & Minimal food waste can be anticipated ${ }^{d}$ \\
\hline
\end{tabular}

\footnotetext{
a Some people who had attended will not eat the food prepared as they were supposed to enjoy it with the sacrificed cow, they believe that ancestor has turned their back on that ritual and would not want to associate themselves with the ritual any further. This constitutes to food waste "Men have their three-legged pots were they prepare pap and slaughter cow meat for "Bann ba Kgoro" (men of the clan/family) only. Women prepare their pap, meat, and sa

lads for the rest of the people attending the ceremony. More of the food prepared by "Banna ba Kgoro" will be wasted by women as they are more westernized, and they already catered for

c Swati wedding can last up to 5 days, and all these days are celebrated consecutively (bridal party to gift offering), people that attend all these ceremonies are the same from day 1 to day 5 thus high food wastage can be anticipated. All these days are celebrated consecutively

'Minimal food waste because they are an isolated culture and rarely mix with other cultures, during events only their cultures' favorite food is being prepared

*NB

$X$ Means it is prepared for either a wedding, funeral, or both events

Yes means an invitation is sent out to people and admission to the wedding is granted by invite

No means invitation etiquette is not administered; the whole community including friends, family, and relatives are invited

Salad means a cold dish of various mixtures of raw or cooked vegetables, usually seasoned with oil, vinegar, or other dressing and sometimes accompanied by meat, fish, or other ingredients
} 
fish, offal, and oranges as they fear it will affect the mother or the child negatively ([53]). Table 2 also expresses that another contributor to food waste in black cultural weddings is not practicing invitation etiquette leading to preparation of large quantities of food for a few people.

Sepedi culture shows to have more potential of wasting more food than other cultures in wedding ceremonies as men cook separately and have their pots; and women also prepare the same food for the rest of the community. However, younger men still find themselves indulging in the food prepared by women rather than eating the food catered for them. In the Swati culture, it can be expected to see a great wastage of food as the same group of people (family and friends) are invited to a wedding that is 5 days long wedding event. Each day food is prepared in large quantities. Hence, rituals are still sacred and unique to each culture where the staple food of a specific culture is also prepared.

Above all, funerals of black people (Africans) are attended by everyone in the community, immediate and extended family, people from all over who want to show support to either the deceased or their family member. Sometimes they attend funerals just for a meal. To this end; its estimation on how many people will be present becomes very complex. More food waste is generated as the preparation of food is done in large quantities. On the contrary, funerals of white South Africans are usually small and private. Only friends and family members are notified of the death, thus catering for a few attending. Therefore, tea and sandwiches are prepared which result in reducing the chances of food waste generation. During a funeral a lot of food can go to waste. The differences in culture, ethnicity, and preferences of ethnic foods play a significant role. The reason behind it is that most families do not want to let down their family and think of doing well to the deceased by offering more food. Hence, the worst fear that families have is to hear the people's comments saying "there was not enough food" as it automatically becomes a disgrace.

A study conducted by Ndeleni [54] indicated that people attend funerals even if they did not know the deceased nor the family for social and cultural reasons; this is common even in poor families. It should be acknowledged that with the high price of food and some people being unemployed; most cannot afford to eat in restaurants and nice foods anymore. So funerals become a place where decent food can be accessible. This also depends on the socio-economic status of the family where there is a funeral. The richer will prepare the best, whereas the poor will prepare only what they have. Hence the diversity between the "haves and the have nots" will determine the amount of food wasted. This may be the reason why specific catering is not apprehended by families as they understand better their people and their issues. Ndinisa [45] went on to say "We gather to be fed by the mourners for at least two weeks' prior the burial." This can only impact on food waste as more and more food needs to be prepared before the funeral. Therefore, if catering focused more on close friends and relatives less food would be wasted during such events.

Zulu people have multiple ceremonies for the funeral; they believe that the spirits of the dead will wander around if they do not make another ceremony a year after the burial to ritually bring the ancestors back home; it is believed that if it is not done, it could bring bad luck to the family. Maize meal is prepared and the sacrifice of an animal is made which could lead to a wastage of food. However, in other cultures; the collection of the spirit is done before the burial [45]. Hence, the diversity of cultures in South Africa differs in how food is wasted. Social events in South Africa are becoming a great deal of expenditure as families felt the need to prove that they are not poor. In so doing, they cook too much food that ends up being wasted. Therefore, communities should be taught that invitations and catering should form part of the organization of the event and should made to understand that events are the main reason for gathering and must not be based on how much food is catered.

\section{Culture of the wealthy}

People who are on the highest level of the socio-economic pyramid maintain a certain standard in society and behave in a certain way which is referred to as the "culture of the rich." Wealthy people see the world differently than the poor [19]. The author further suggested that people with higher status have reduced empathy which makes it easy for them to be wasteful. Wealthy people throw parties spontaneously and intermittently. India's wealthy surge and rapid economic growth have allowed the families to throw extravagant displays of food to show off their newly discovered affluence [55]. Around 100,000 weddings and social events are held daily in India and 15-20\% of the food prepared is wasted which can easily go to $20-25 \%$ should the number of dishes exceed the number of guests invited to the marriage halls [55]. This is happening in a country where $42 \%$ of the world's underweight children live [56]. Food waste by the wealthy is quite significant and occurs throughout the globe even in the poorest countries such as Kenya. According to Ndengo [2], rich people in Kenya waste about 14,000,000 kg of food weekly through consummation which could feed 230 million starving Africans and the reason attributed to this is the lack of empathy.

South Africa is not different from other African countries. A new practice for the wealthy has erupted in the townships of Gauteng where young boys and girls calling themselves "izikhotane" throw food such as chicken and custard to the ground and destroy it in front of their 
peers. People such as izikhotane deem this behavior to be necessary so that they can show their improved or high ranking socio-economic standing [16]. Koeng is a psychologist who believes that people cannot change their unhealthy eating habits and wasting of food unless they change their underlying beliefs about food, body, or weight [16]. Communities should be encouraged to respect and value food, and they should be encouraged to dish up what they can finish. This is more important to women as in most cases they are the ones who carry the responsibility of raising kids.

Wealthy women, by nature, become role models to a large number of young girls globally. These young girls look up to them and tend to want to be their mirror images of becoming slim and sexy by copying what they are doing. This was highlighted by Boyse [57] stating the trend of eating disorders that are common in highincome groups. The author further indicated that eating disorders such as anorexia nervosa mostly manifest between teenage girls and young women due to the pressure to achieve the bodies portrayed by their role models or the media [58]. According to Boyse [57], it is estimated that $1 \%$ of white females have anorexia nervosa. Anorexic teenage girls begin by restricting themselves of food to look slim, when their parents dish up for them they hide the food and discard it without the knowledge of their parents [59], and such behavior amounts to food waste. This type of culture wastes a significant amount of food for popularity and social standing, and it is therefore of utmost importance to educate the community on how wasting food is equivalent to wasting money. In addition, it must be highlighted to the community that it is not necessary to discard food to get approval from other people as it not only affects their reputation but cost the environment and the economy as well. Empathy cannot be forced into a person; however, prevention of food waste should be emphasized whereby people are encouraged to donate to those who are less fortunate and help end the world's hunger or starvation. This will make wealthy people to become role models who promote self-love and would allow them to minimize food waste and in turn reduce the impact they cause on the environment due to food waste.

\section{Culture of poverty}

Alcock [29] defines poverty as having to spend less on food, clothing, and other necessities because you are short materially, socially, and emotionally which inevitably takes away the ability to improve your life chances. In a quest to improve their lives, 11.4 billion poor people in South Africa appear to commit to stokvels (a society for saving or investing money, done in groups [60]) that generate R44 billion per annum which they use to buy groceries [61]. The author further stated that these stokvel groups tend to send big trucks to buy large amounts of food during specials even those with as little as a $1 \%$ discount. There is a concern that if people buy such an amount of food at once that they might not be able to consume it completely, it may lead to the food being spoiled before consumption. Unfortunately, this has become a culture where the attitudes and behaviors are passed down to subsequent generations and is termed a "culture of poverty" which was also experienced in the early 1950s [12].

High priority food items that are mostly wasted by poor South Africans are pap and bread. What is not communicated is the adverse impact of food wastage. If food is wasted the need to produce more food is inevitable which in turn pushes the prices even higher, making it harder for the poor to afford [62]. In South Africa, 12 million people go to bed hungry every night [63] and $90 \%$ of poverty marginalized people spend their annual budget on festivals when contrasted with Pakistan, Indonesia, and Cote d'Ivoire $50 \%$ of them do likewise [64]. The main challenge during weddings and funerals of South Africans is the need to prove themselves to the rest of the community that they can also afford a certain lifestyle even if it gets them into debt. Unfortunately, their cultural practices force them to cook too much food that does not get eaten which results in food waste, making the prevention of food waste to be more complex in South Africa.

\section{Discussion}

South Africa is a developing country with an economy that is continuously challenged. However, the country continues to waste about 10 million tonnes of food on a year-to-year basis which translate to R6 400,000 [13]. This is happening in a country where people go to bed hungry every night. The review article found that it appears as though the main contributing factors of food waste range from food supply chain to consumer behavior.

The behavior of consumers is influenced by values and beliefs which in turn are shaped by their cultures [50]. The teachings of these various cultures have a huge impact on the continuous increase of food waste, much food is wasted during funerals and weddings as cultural aspects come into play. In some South African cultures, a funeral can have multiple ceremonies from the collection of the spirit [45], cleansing of the people left behind to the actual funeral itself. All these include preparation of food that alone has the potential to food waste. The preparation of overgenerous portions and the nonconsumption of food is the leading cause of food waste [51] in South African ceremonies. South Africa is comprised of both the poor and wealthy cultures and their behavioral patterns show a great variation. According to Stats South Africa [65], poor households spend roughly $34 \%$ of their annual income on food; mainly maize and 
bread, these food items happen to be what gets wasted the most. Furthermore, it is reported that the non-poor households spend only $10 \%$ of their annual income on food and they mostly purchase meat and fish. These two cultures purchase and consume different types of food items, host ceremonies for various reasons but what they have in common is that after an event is hosted by either, food is left to waste. In some parts of Africa food is valued more and the practice of Ubuntu allows for the conservation of food, by giving leftover food to somebody who needs it.

The Western culture shows little waste in terms of ceremonies as their catering is based on the response to the invitation and most of their events are small and intimate. However, affluent countries show very little value of food because it is available to them in large quantities at low cost [4]. On the other hand, this act of not valuing food seems to be a common practice for wealthy people even if they are not in affluent countries. A practice of "Izikhotane" has quickly spread in South Africa where they show off their wealth by destroying food items in front of their peers just for fun, but it amounts to food waste.

\section{Conclusion}

Food waste is a social problem, it is not only about losing food, but it also involves the loss of energy, water, labour, and financial resources that came into the part for its production. All of which harm the environment and the economy. It is evident from the findings that culture plays a major role in food waste. In South Africa food is an integral part of cultural heritage and national identity because of this it is either wasted or valued more. Strict invitation etiquette is not practiced, which leads to food waste during social events because food is prepared in large quantities for people whose number is not known. Food waste is also an issue of empathy; in the poorest of countries wealthy people still waste food while others go hungry. This is not a presupposition that all African societies have the same explanation for events but rather there are underlying similarities shared by many African societies.

Residents of affluent countries tend to waste more food as compared to residents of developing countries because food is made available at low prices that influence their value of food [4]. Ceremonies of the western culture are all about etiquette which involves a specific number of people who are attending the event thus food waste in such events is at a minimum. The perception that only rich people waste food is proven to be incorrect and ultimately food waste exists in both the culture of the rich and the poor. The difference is the type and quantity of food being wasted.

Educating people alone may not reduce food waste because knowing and valuing food is not enough to change norms. However, a culturally centered approach that is directly linked to food waste can work to curtail the quantity and impact of food waste. It is therefore important to understand the diversity of cultures in its variance to make an appropriate intervention that could reduce the impact of food waste on the environment. Hence, it is more evident that there are still areas of culture and food waste that could be explored by researchers to identify other contributing factors that may increase food waste that might not have been explored in this paper.

\section{Recommendations}

To address the challenge of food waste, use a "culture-centered approach" [66] that moves away from the view of food waste as the only consumer preference issue, other factors need to be considered and addressed appropriately.

- Focus on modifying cultural ways to reduce and avoid food waste by cooking minimal food but not completely parting with original cultural practices.

- Introduce invitations etiquette and strictly adhere to it. This will minimize the amount of food waste during social events as the hosts will be able to cater for the specific amount of guests expected.

- Provide education and raise awareness to communities regarding the impact of food waste on the environment and the economy by emphasizing that wasting food is equivalent to wasting money.

- Encourage or Instil the spirit of Ubuntu in both the African and western cultures and also encourage the eating of leftovers or sharing of food with the neighbours or the needy.

\section{Acknowledgements}

The authors acknowledge Tshwane University of Technology and National Research Foundation for their support.

\section{Authors' contributions}

LP was involved in conceptualizing and developing the methodology. LSM modified the framework of the study and was involved in editing. The other authors (GFM, MIM, TJM, MMM) contributed to review and editing of the manuscripts, from the first draft to the final version. All authors read and approved the final manuscript.

\section{Funding}

This research received no external funding.

Availability of data and materials Not applicable

\section{Competing interests}

The authors declare that they have no competing interests.

Received: 27 November 2019 Accepted: 18 August 2020

Published online: 01 October 2020

\section{References}

1. Kibler KM, Reinhart D, Hawkins C, Motlagh AM, Wright J. Food waste and the food-energy-water nexus: a review of food waste management alternatives. Waste Manag. 2018;74:52-62. 
2. Ndego M, Food waste: comparison between the rich and the poor in Kenya. 2015. https://prezi.com/2kja0gxfumwt/food-waste-comparisonbetween-the-rich-and-the-poor-in-kenya.

3. Fox T. Global food. Waste not, want not. Institute of Mechanical Engineers (IME). 2013. https://www.imeche.org/docs/default-source/default-documentlibrary/global-food---waste-not-want-not.pdf?sfvrsn=0.

4. Aschemann-Witzel J, de Hooge I, Amani P, Bech-Larsen T, Oostindjer M. Consumer-related food waste: causes and potential for action. Sustainability. 2015;7:6457-77.

5. Fine Dining Lovers (FDL). LA Tomatina festival a crazy feast in Spain. 2015. https://www.finedininglovers.com/stories/tomatina-festival-spain/.

6. Cendrowicz L. 2009. Europe farmers spill milk to decry tumbling prices. Time newspaper. 2009. http://content.time.com/time/business/article/0,85 99,1925163,00.html.

7. Scientific American. Statistically speaking: a wasteland of food. 2014. https:// www.scientificamerican.com/article/statistically-speaking-a-wasteland-offood/.

8. Tiwari S. World has 7.5 billion people and produces food for 12 billion, but still millions go hungry! India times. 2017; https://www.google.co.za/amp/s/ amp.indiatimes.com/news/india/world-has-7-5billion-people-and-producesfood-for-12-billion-but-still-millions-go-hungry-274297.

9. UNITED NATIONS. World population prospects: the 2017 revision. 2017. https://www.un.org/development/.../world-population-prospects-the-2017revision.html.

10. UNEP and FAO. Global campaign to change the culture of food waste launched. 2013,

11. Clover J. Food security in sub-Saharan Africa. Afr Secur Stud. 2003;12:5-15.

12. Lewis O. Five families: studies in the culture of poverty. Mexican case international encyclopedia of the social science 1959. https://www. encyclopedia.com/social-sciences-and-law/sociology-and-social-reform/ sociology-general-terms-and-concepts/culture-poverty.

13. World Wildlife Fund. The food loss and waste: facts and futures report. 2017. http://www.wwf.org.za/?21962/The-truth-about-our-food-waste-problem.

14. Hebrok M, Boks C. Household food waste: drivers and potential intervention points for design: an extensive review. J Clean Prod. 2017;151:380-92.

15. [Internet] available from https://en.oxforddictionaries.com/definition/ rainbow_nation.

16. Puoane T, Matwa P, Bradley H, Hughes G. Socio-cultural factors influencing food consumption patterns in the black African population in an urban township in South Africa. University of Western Cape; 2006

17. Baer D, Rich people literally see the world differently science of US barilla center for food and nutrition (BCFN). Food wastes: causes, impacts and proposals. 2017. https://www.sbs.com.au/topics/life/culture/article/2017/03/ 02/rich-people-literally-see-world-differently.

18. [Internet] available from https://www.merriam-webster.com/dictionary/ culture.

19. Tey YS, Arsil P, Brindal M, Liew SY, Teoh TC, Terano R. Personal values underlying ethnic food choice: means-end evidence for Japanese food. J Ethnic Foods. 2018:5:33-9.

20. Heggertveit-Aoudia S. Culture, values and the impact at work. Profiles in diversity journal. 2012. http://www.diversityjournal.com/9823-culture-valuesand-the-impact-at-work/

21. Parfitt J, Barthel M, Macnaughton S. Food waste within food supply chains: quantification and potential for change to 2050. Philos Trans R Soc. 2010; 365:3065-81.

22. World Health Organisation (WHO) and Food and Agricultural Organisation (FAO) of the United Nations. Diet, nutrition and the prevention of chronic diseases. WHO technical report series. 2003; http://www.fao.org/docrep/005/ AC911E/ac91 1e05.htm\#bm05.

23. Onwumere O. Nigeria wastes $40 \%$ of food but millions of citizens are dying of hunger: the Nigerian voice. 2018. https://www.thenigerianvoice.com/ news/262345/nigeria-wastes-40-of-food-but-millions-of-citizens-are-dyin. html.

24. Stenmarck A, Jensen C, Quested T and Moates G. Estimates of European food waste levels: reducing food waste through social innovation. 2016. ISBN 978-91-88319-01. http://www.eu-fusions.org/ phocadownload/Publications/Estimates\%20of\%20European\%20food\%2 Owaste\%20levels.pdf.

25. United States Department of Agriculture (USDA). USDA's economic research service. 2010. Accessed at https://www.usda.gov/oce/foodwaste/fags.htm on 09 Oct 2018.
26. World Economic Forum. Food: how much does the world need? 2015. https://www.weforum.org/agenda/2015/05/food-how-much-does-theworld-need/.

27. Nahman A, Willem de Lange W, Oelofse S, Godfrey LB. Waste Manag J. 2012;32:2147-53.

28. Oelofse S. Quantifying the cost of food waste in South Africa. CSIR. 2013. https://www.csir.co.za/quantifying-cost-food-waste-south-africa.

29. Alcock P. Understanding poverty. New York: Palgrave; 1997.

30. Mccraken M. Which countries waste the most food? 2018. https://www. care2.com/greenliving/which-countries-waste-the-most-food.html.

31. Ross S. 4 countries that produce the most food. Investopedia. 2018. https:// www.investopedia.com/articles/investing/100615/4-countries-produce-mostfood.asp\#ixzz5VJMKpfLY

32. Dawson C. The study of western culture. Chapter IX in the crisis of western education; 1960. p. 119-28. https://www.catholiceducation.org/en/ education/catholic-contributions/the-study-of-western-culture.html.

33. Idang GE. African culture and values Gabriel E department of philosophy. Uyo: University of Uyo; 2015.

34. Perkins K. Social norms in the eastern and western cultures: presentation for PSYC335 cultural psychology. 2012. https://prezi.com/lkuk7vtu3_pd/socialnorms-in-the-eastern-and-western-cultures/.

35. Maluleke MJ. Culture, tradition, custom, law and gender equality per. PELJ. 2012;15:1 http://www.scielo.org.za/pdf/pelj/v15n1/v15n1a01.pdf.

36. Markwell $L$ Waste not, want not: western culture of binning food. Independent. 2012. https://www.independent.co.uk/voices/comment/wastenot-want-not-the-western-culture-of-binning-food-8205844.html.

37. Rogak L. Death warmed over: a funeral food cookbook. 2013. https://www. amazon.com/Death-Warmed-Over-Funeral-Rituals/dp/1580085636on.

38. Ngcobo N. The difference between white funerals and black funerals. My broadband. 2015. https://mybroadband.co.za/vb/showthread.php/691654The-difference-between-white-funerals-and-black-funerals.

39. Malone S. How catering works at a destination wedding: a bridal etiquette primer, HuffPost. 2013; https://www.huffingtonpost.com/sandy-malone/ how-catering-works-at-a-d_b_3314695.html.

40. Nussbaum B. African culture and Ubuntu reflections of a south African in America. World Bus Acad. 2003;17.

41. [Internet] available from https://www.everyculture.com/Sa-Th/Sierra-Leone. html.

42. [Internet] available from, https://www.google.co.za/amp/s/bionerdsng com/2016/04/14/the-new-yam-festival/amp.

43. Abdulhalim L. The Swahili wedding. Strokes of my pen. 2014. http://lubnah. me.ke/the-swahili-wedding/.

44. Zondo M. Why are black funerals so expensive? News 24. 2017. https://m. news24.com/Columnists/Mondli_Zondo/why-are-black-funerals-soexpensive-20171024/comment

45. Ndinisa N. The extravagance and waste of funerals. African identity. 2014. https://thisisafrica.me/extravagance-waste-funerals/.

46. Ramkissoon N, Nagel A, and Boikanyo R. Wedded to our traditions. Timeslive: Sunday times. 2012. https://www.timeslive.co.za/news/southafrica/2012-08-23-wedded-to-our-traditions/.

47. Sangkyun AS, Long KP. Minority cultural festival: travel and amp tourism Marketing. 2012;29:682-94

48. Misachi J. South African culture, customs and traditions: the culture of South Africa is one of the most diverse in the world. 2018. https://www. worldatlas.com/articles/south-African-culture-customs-andtraditions.html.

49. Stats South Africa (Stats). Census 2011. http://www.statssa.gov.za/?page_id= 3839 .

50. Cummins E. The connection between food, culture \& society. 2018. https:// study.com/academy/lesson/the-connection-between-food-culture-society.html.

51. Barilla Center for Food and Nutrition (BCFN). Food waste: causes, impacts and proposal. 2012. https://www.barillacfn.com/m/publications/food-wastecauses-impact-proposals.pdf.

52. Mhlana ON. The cow: a bridge between the living and the dead. 2013. http://www.archivalplatform.org/blog/entry/the_cow_a_bridge_between_ the_living_and_the_dead/.

53. Chakona $\mathrm{G}$ and Shackleton C. Fdsqood taboos and cultural beliefs influence food choice and dietary preferences among pregnant women in the eastern Cape South Africa nutrients. 2019. https://www.researchgate.net/ publication/337021966_Food_Taboos_and_Cultural_Beliefs_Influence_ Food_Choice_and_Dietary_Preferences_among_Pregnant_Women_in_the_ Eastern_Cape_South_Africa. 
54. Ndeleni L. Cultural and Western funeral traditions, a cultural exploration Space admin. 2016. https://www.blc.co.za/cultural-western-funeral-traditionscultural-exploration-lunga-ndeleni/.

55. Venuemonk. Food wastage in Indian weddings and parties. 2016. https:// blog.venuemonk.com/2016/06/06/food-wastage-in-indian-weddings-andparties/.

56. Smith $\mathrm{CL}$. The great Indian calorie debate: explaining rising undernourishment during India's rapid economic growth. Food Policy. 2015; 50:53-67.

57. Boyse K. Eating disorders: what families need to know Michigan medicine Michigan University. 2010. http://www.med.umich.edu/yourchild/topics/ eatdis.htm\#top.

58. Saul JS, Rodgers RF. Adolescent eating disorder risk and the [online world]. Child Adolesc Psychiatr Clin N Am. 2018;27:221-8.

59. Health Experience Research Group (HERG). Oxford University. 2015. www. healthtalk.org/young-peoples-experiences/eating-disorders/secrecy-andeating-disorders

60. Oxford dictionary; https://www.lexico.com/en/definition/stokvel.

61. Mulaudzi R. SA Stokvels generate R44bn each year - but members reap little reward. Graduate School of Business University of Cape Town. 2017. https:// www.gsb.uct.ac.za/stokvels.

62. Hurford P. How do the extremely poor live? Everyday utilitarian. 2014 http://everydayutilitarian.com/index.htmlon.

63. Molelekwa T. Wasting food while others are hungry. Health E News. 2018; https://www.health-e.org.za/2018/06/20/the-problem-of-food-waste-insouth-africa/.

64. Banerjee AV, Duflo E. The economic lives of the poor. J Econ Perspect. 2007; 21:141-67.

65. Stats SA. Poor households spend a third of their income on food. 2014. http://www.statssa.gov.za/?p=2564.

66. Benecke DR, Simpson Z, Le Roux S, Skinner CJ, Janse van Rensburg N, Sibeko J, Bvuma S, Meyer J. Review cultural intermediaries and the circuit of culture: the digital ambassadors project in Johannesburg, South Africa. Public Relat Rev. 2017;43:26-34.

\section{Publisher's Note}

Springer Nature remains neutral with regard to jurisdictional claims in published maps and institutional affiliations.

Ready to submit your research? Choose BMC and benefit from:

- fast, convenient online submission

- thorough peer review by experienced researchers in your field

- rapid publication on acceptance

- support for research data, including large and complex data types

- gold Open Access which fosters wider collaboration and increased citations

- maximum visibility for your research: over $100 \mathrm{M}$ website views per year

At $\mathrm{BMC}$, research is always in progress.

Learn more biomedcentral.com/submissions 